\title{
Accumulation of Heavy Metals in Feral Pigeons Living Near a Ferronickel Smelter
}

\author{
Albana Plakiqi Milaimi ${ }^{1 *}$, Qerim Selimi ${ }^{1}$, Kasum Letaj ${ }^{1}$, \\ Artan Trebicka ${ }^{2}$, Astrit Milaimi ${ }^{3}$ \\ ${ }^{1}$ Department of Biology, University of Prishtina, P.O. Box 10.000 Prishtina, Republic of Kosovo \\ ${ }^{2}$ Department of Biology, Faculty of Natural Sciences, University of Tirana, Republic of Albania \\ ${ }^{3}$ HazizTola Primary and Lower Secondary School, Prizren, Republic of Kosovo
}

Received: 10 March 2016

Accepted: 29 May 2016

\begin{abstract}
The aim of this study was to determine the effects of a ferronickel smelter in Drenas, Kosovo, in concentrations of lead, cadmium, zinc, copper, and nickel in tissues of liver, kidney, testes, femur, and tibia of feral pigeons (Columba livia). For this purpose, we took 20 birds (nine male and 11 female) from the ferronickel smelter courtyard, and 20 (11 male and 9 female) from Lubizhdë village (control group) to assess the accumulation of heavy metals ( $\mathrm{Pb}, \mathrm{Cd}, \mathrm{Zn}, \mathrm{Cu}, \mathrm{Ni}$ ) in soft tissues (liver, kidney, and testes) and solid tissues (femur and tibia). We found that lead $(\mathrm{Pb})$ concentrations in the liver, kidney, femur, and tibia increased in the Drenas group $(\mathrm{P}=0.160, \mathrm{P}=0.176, \mathrm{P}<0.001, \mathrm{P}<0.001)$, whereas lead concentration decreased in the testes compared to the control group $(\mathrm{P}=0.030)$. Cadmium $(\mathrm{Cd})$ concentrations in the liver and kidney increased $(\mathrm{P}=0.460, \mathrm{P}<0.001)$, whereas in other tissues it is not found. Zinc $(\mathrm{Zn})$ concentrations in the liver, kidney, and tibia tissues increased $(\mathrm{P}=0.050, \mathrm{P}=0.094, \mathrm{P}=0.258)$, whereas in the testes and femur it decreased $(\mathrm{P}<0.001, \mathrm{P}=0.556)$. Copper $(\mathrm{Cu})$ concentrations increased in the liver, kidney, testes, and tibia tissues $(\mathrm{P}<0.001, \mathrm{P}<0.001, \mathrm{P}<0.001, \mathrm{P}=0.007)$, but decreased in the femur tissue $(\mathrm{P}=0.456)$ compared to the control group. Nickel $(\mathrm{Ni})$ concentrations increased in all examined tissues $(\mathrm{P}<0.001$, $\mathrm{P}=0.010, \mathrm{P}=0.292, \mathrm{P}=0.312, \mathrm{P}=0.102$ ) of feral pigeons (Columba livia) from the smelter courtyard. The highest concentration of Ni was recorded in the liver $(139.97 \mu \mathrm{g} / \mathrm{mg}$ d.w.).
\end{abstract}

Keywords: environmental pollution, heavy metals, soft tissues, solid tissues, nickel metallurgy

\section{Introduction}

Environmental pollution is a global problem that affects all aspects of life. With the development of industry and urbanism, different pollutants are being released continuously into the ecosystem, bringing disorder, imbalance, and the impossibility of self-regulation. These

*e-mail: aplakiqi@ymail.com effects are being felt by living organisms. The particular problem is pollution that comes from metallurgy, whose processes may release heavy metals that can affect living organisms and cause numerous disorders and diseases. As a result, many heavy metals are present in the environment. They are released in the form of oxides in the air and as salts in the soil and water. It was found that they have toxic, carcinogenic, and mutagenic effects on animals and humans [1-4]. As a component of Earth's 
crust, heavy metals are present in low concentrations in all environmental components. Being present in the air, water, and soil, they are able to enter the body and then the food chain, where their levels are multiplied a hundred times by passing from prey to predator, which is the phenomenon of biomagnification [5].

Some heavy metals are essential for functioning organisms $(\mathrm{Zn}, \mathrm{Cu}, \mathrm{Ni}$, etc.), but they may be toxic in higher concentrations. Other metals $(\mathrm{Pb}, \mathrm{Cd}, \mathrm{As}$, etc.), are toxic even in low concentrations [6]. Animals may be exposed to heavy metals as a result of contamination of drinking water, contaminated air, and food near the emission. Toxicity manifestation depends on many factors, such as dose, duration of exposure, species, sex, environmental factors, and feeding habits [7]. Heavy metals such as $\mathrm{Pb}$ and $\mathrm{Cd}$, after entering the body, enter the biochemical cycles, bind with ligands, and - due to their similar chemical structure with zinc - after a long time of exposure can accumulate in the target organs [7-8]. The target organs are unable to metabolize the heavy metals due to their atomic weight and high density. Some of these metals affect enzymatic systems because they can bind with specific proteins and compete with other essential substances. In this way heavy metals affect cell functions and can form anions and superoxides, which are toxic and can cause cell death. For instance, lead has no biological role, but even at low concentrations it is toxic for living organisms by inhibiting the synthesis of hemoglobin through inhibition of the $\delta$-Aminolevulinic acid enzyme $[6,9]$.

Long-term exposure, even in low doses, may lead to chronic intoxication [7, 9]. Each of the heavy metals $(\mathrm{Pb}, \mathrm{Cd}, \mathrm{Cr}, \mathrm{Ni}, \mathrm{As}, \mathrm{Hg}, \mathrm{Be}, \mathrm{Cu}, \mathrm{Zn})$ has a tendency to accumulate in organisms in general and in target organs in particular. In addition, $\mathrm{Pb}$ can be accumulated in the liver, kidney and bones; $\mathrm{Cd}$ in kidney and testes; $\mathrm{Zn}$ in bones (when $\mathrm{Pb}$ and $\mathrm{Cd}$ concentration also is high); $\mathrm{Ni}$ in kidney and testes; and $\mathrm{Cu}$ in liver and kidney. In these organs they can cause toxicity and after long-term exposure they can cause cancer [7-8, 10-11].

Heavy metals accumulation was found in mammals and birds living near heavy metal mines and smelters [9, 12]. Due to their higher metabolism, feral pigeons can accumulate more lead than mammals $[8,13]$, especially those living near mines, and those consuming food along roads where the dust contains lead.

The area near the ferronickel smelter has been reported to be polluted by such heavy metals as lead, cadmium, zinc, copper, and nickel [1, 14]. This has prompted us to study whether these heavy metals were accumulated in the body. Referring to other authors who have reported the target organs for $\mathrm{Pb}, \mathrm{Cd}, \mathrm{Zn}, \mathrm{Cu}$, and $\mathrm{Ni}$, we were determined to study the accumulation of these metals in the liver, kidney, testicles, femur, and tibia [8-9, 15-17].

Feral pigeons are ubiquitous and non-migratory. They are granivours, but also feed on invertebrates. They are synantropic and live in urban areas with high automobile traffic densities, and in areas with high levels of lead in roadside dust. Due to their higher metabolism, they can survive after accumulating high levels of lead and cadmium [16].

However, there is little evidence of the effects of ferronickel smelters regarding concentrations of heavy metals ( $\mathrm{Pb}, \mathrm{Cd}, \mathrm{Zn}, \mathrm{Cu}, \mathrm{Ni}$ ) in the soft (liver, kidney, testes) and solid (femur and tibia) tissues in the area of Drenas, Kosovo, and little information about nickel accumulation in the tissues of feral pigeons. Our purpose is to assess pollution by heavy metals and their bioaccumulation in these tissues.

\section{Study Area, Materials and Methods}

Drenas is a city with traffic, urban, and metallurgical pollution. The New Ferronickel smelter is located in Drenas, $20 \mathrm{~km}$ from Pristine, capital city of Kosovo. It has been operating since 1982. The final products of the smelter are iron and nickel. The gas, dust, and ash emitted by the smelter over the years contain significant amounts of heavy metals. The ash is deposited near the Drenica River, and heavy metals concentrations $(\mathrm{Pb}=0.0998$ ppm, $\mathrm{Cd}=0.00 \mathrm{ppm}, \mathrm{Zn}=0.1012 \mathrm{ppm}, \mathrm{Cu}=0.0260 \mathrm{ppm}$, $\mathrm{Ni}=0.2546 \mathrm{ppm})$ were reported in Drenica water [14], where the smelter discharges its waste. In sludge of the river the composition was: $\mathrm{Pb}=121.00 \mathrm{ppm}$, $\mathrm{Zn}=2541.00 \mathrm{ppm}, \mathrm{Cu}=50.90 \mathrm{ppm}, \mathrm{Cd}=0.00 \mathrm{ppm}$, and $\mathrm{Ni}=4035.00 \mathrm{ppm} \mathrm{[1]}$. The presence of heavy metals in the ash and soil also has been reported (in the ash: $\mathrm{Pb}=16.21 \mathrm{ppm}, \mathrm{Zn}=19.10 \mathrm{ppm}, \mathrm{Cu}=5.50 \mathrm{ppm}$, $\mathrm{Cd}=0.00$ ppm, $\mathrm{Ni}=260.50 \mathrm{ppm}$; in the soil: $\mathrm{Zn}=97.00$ ppm, $\mathrm{Pb}=55.50 \mathrm{ppm}, \mathrm{Cu}=22.60 \mathrm{ppm}, \mathrm{Cd}=0.00 \mathrm{ppm}$, $\mathrm{Ni}=107.80 \mathrm{ppm})[1]$. The chemical composition of the air consists of $\mathrm{Fe}=0.068(\mathrm{mg} / \mathrm{l}), \mathrm{Ni}=0.006, \mathrm{Co}=0.043$, $\mathrm{Cr}=0.01$; and gases, such as $\mathrm{CO}=10.65, \mathrm{CO}_{2}=7.7$, $\mathrm{SO}_{2}=310, \mathrm{NOx}=54$ [18].

Specimens of feral pigeon (Columbia Livia) (20 birds, weight $=276 \pm 30.33 ; 11$ male, weight $=284 \pm 77$; nine female, weight $=270.45 \pm 31.69)$ were collected in the smelter courtyard in Drenas (April 2015) and in the control area of Lubizhdë village ( 20 birds, weight $=262 \pm 23.65$; 9 male, weight $=271 \pm 26.71 ; 11$ female, weight $=252 \pm 14.6$ ). Birds were killed by cervical dislocation and the tibia, femur, liver, kidney, and testes were excised and the tissues dried at $100^{\circ} \mathrm{C}$ for $48 \mathrm{~h}$ and dry-ashed as described by Blanusa and Breski [19]. Tissue concentrations of $\mathrm{Pb}$, $\mathrm{Cd}, \mathrm{Zn}, \mathrm{Cu}$, and $\mathrm{Ni}$ were measured using flame atomic absorption spectrophotometry (Unicam 929).

\section{Results and Discussion}

Results of tissue concentrations of $\mathrm{Pb}, \mathrm{Cd}, \mathrm{Zn}, \mathrm{Cu}$, and $\mathrm{Ni}$ in the liver, kidney, testes, femur, and tibia are summarized in Table 1.

Lead $(\mathrm{Pb})$ concentrations in the liver, kidney, femur, and tibia increased in the Drenas group $(\mathrm{P}=0.160$, $\mathrm{P}=0.176, \mathrm{P}<0.001, \mathrm{P}<0.001)$, whereas in the testes, 
Table 1. Heavy metal concentrations ( $\mu \mathrm{g} / \mathrm{mg}$ d.w.) in soft tissues (liver, kidneys, and testicles), and in solid tissues (femur and tibia) of feral pigeons (Columba livia) from the ferronickel smelting area in Drenas (control) and Lubizhdë (reference).

\begin{tabular}{|c|c|c|c|c|c|c|}
\hline Tissues & Locality & $\mathrm{Pb}$ & $\mathrm{Cd}$ & $\mathrm{Zn}$ & $\mathrm{Cu}$ & $\mathrm{Ni}$ \\
\hline LIVER & $\begin{array}{c}\text { DRENAS } \\
\text { A } \\
\text { LUBIZHDË } \\
\text { B }\end{array}$ & $\begin{array}{c}17.43 \pm 8.13 \\
(20) \\
13.04 \pm 5.95 \\
(12)\end{array}$ & $\begin{array}{c}0.52 \pm 0.34 \\
(20) \\
0.44 \pm 0.2 \\
(20)\end{array}$ & $\begin{array}{c}159.56 \pm 46.4 \\
(20) \\
126.56 \pm 31.9 \\
(20)\end{array}$ & $\begin{array}{c}18.48 \pm 5.43 \\
(20) \\
13.08 \pm 3.38 \\
(20)\end{array}$ & $\begin{array}{c}139.97 \pm 67.8 \\
(14) \\
2.75 \pm 1.03 \\
(10)\end{array}$ \\
\hline SIGNIFICANCE & A : B & $\begin{array}{c}(\mathrm{P}=0.160) \\
\mathrm{NS}\end{array}$ & $\begin{array}{c}(\mathrm{P}=0.460) \\
\mathrm{NS}\end{array}$ & $(\mathrm{P}=0.050)$ & $(\mathrm{P} \leq 0.001)$ & $(\mathrm{P} \leq 0.001)$ \\
\hline KIDNEY & $\begin{array}{c}\text { DRENAS } \\
\text { A } \\
\text { LUBIZHDË } \\
\text { B }\end{array}$ & $\begin{array}{c}77.17 \pm 30.8 \\
(20) \\
60.69 \pm 25.5 \\
(13)\end{array}$ & $\begin{array}{l}0.88 \pm 0.61 \\
(20) \\
0.07 \pm 0.04 \\
(10)\end{array}$ & $\begin{array}{c}142.91 \pm 35.64 \\
(20) \\
125.43 \pm 23.33 \\
(20)\end{array}$ & $\begin{array}{c}29.16 \pm 8.08 \\
(20) \\
12.58 \pm 5.76 \\
(20)\end{array}$ & $\begin{array}{c}18.57 \pm 8.76 \\
(20) \\
8.33 \pm 3.47 \\
(10)\end{array}$ \\
\hline SIGNIFICANCE & A : B & $\begin{array}{c}(\mathrm{P}=0.176) \\
\mathrm{NS}\end{array}$ & $(\mathrm{P} \leq 0.001)$ & $\begin{array}{c}(\mathrm{P}=0.094) \\
\mathrm{NS}\end{array}$ & $(\mathrm{P} \leq 0.001)$ & $(\mathrm{P}=0.010)$ \\
\hline TESTES & $\begin{array}{c}\text { DRENAS } \\
\text { A } \\
\text { LUBIZHDË } \\
\text { B } \\
\end{array}$ & $\begin{array}{c}28.85 \pm 12.67 \\
(10) \\
61.52 \pm 6.68 \\
(3) \\
\end{array}$ & $\begin{array}{l}\text { ND } \\
\text { ND }\end{array}$ & $\begin{array}{c}77.52 \pm 11.12 \\
(10) \\
107.37 \pm 7.22 \\
(10)\end{array}$ & $\begin{array}{c}39.84 \pm 19.43 \\
(10) \\
12.019 \pm 5.07 \\
(20)\end{array}$ & $\begin{array}{c}17.60 \pm 2.39 \\
(10) \\
12.77 \pm 5.49 \\
(6)\end{array}$ \\
\hline SIGNIFICANCE & A : B & $(\mathrm{P}=0.030)$ & & $(\mathrm{P} \leq 0.001)$ & $(\mathrm{P} \leq 0.001)$ & $\begin{array}{c}(\mathrm{P}=0.292) \\
\mathrm{NS}\end{array}$ \\
\hline FEMUR & $\begin{array}{c}\text { DRENAS } \\
\text { A } \\
\text { LUBIZHDË } \\
\text { B } \\
\end{array}$ & $\begin{array}{c}58.38 \pm 22.93 \\
(20) \\
4.27 \pm 1.76 \\
(10)\end{array}$ & $\begin{array}{l}\text { ND } \\
\text { ND }\end{array}$ & $\begin{array}{c}184.77 \pm 39.75 \\
(20) \\
191.50 \pm 26.60 \\
(20)\end{array}$ & $\begin{array}{c}0.8 \pm 0.3 \\
(12) \\
1.31 \pm 0.88 \\
(9)\end{array}$ & $\begin{array}{c}3.48 \pm 1.01 \\
(12) \\
1.35 \pm 0.22 \\
(2)\end{array}$ \\
\hline SIGNIFICANCE & A : B & $(\mathrm{P} \leq 0.001)$ & & $\begin{array}{c}(\mathrm{P}=0.556) \\
\mathrm{NS}\end{array}$ & $\begin{array}{c}(\mathrm{P}=0.456) \\
\mathrm{NS}\end{array}$ & $\begin{array}{c}(\mathrm{P}=0.312) \\
\mathrm{NS}\end{array}$ \\
\hline TIBIA & $\begin{array}{c}\text { DRENAS } \\
\text { A } \\
\text { LUBIZHDË } \\
\text { B } \\
\end{array}$ & $\begin{array}{c}44.93 \pm 16.69 \\
(20) \\
6.02 \pm 0.94 \\
(4) \\
\end{array}$ & $\begin{array}{l}\text { ND } \\
\text { ND }\end{array}$ & $\begin{array}{c}162.50 \pm 28.45 \\
(20) \\
152.8 \pm 18.04 \\
(20) \\
\end{array}$ & $\begin{array}{c}2.74 \pm 1.05 \\
(20) \\
1.12 \pm 0.44 \\
(8) \\
\end{array}$ & $\begin{array}{c}3.42 \pm 1.48 \\
(12) \\
0.82 \pm 0.19 \\
(2) \\
\end{array}$ \\
\hline SIGNIFICANCE & A : B & $(\mathrm{P} \leq 0.001)$ & & $\begin{array}{c}(\mathrm{P}=0.258) \\
\mathrm{NS}\end{array}$ & $(\mathrm{P}=0.007)$ & $\begin{array}{c}(\mathrm{P}=0.102) \\
\mathrm{NS}\end{array}$ \\
\hline
\end{tabular}

Note: Values are expressed as means $\pm \mathrm{SD}$ - standard deviation; NS - non significant; ND - not detected. In parentheses - number of animals, $* \mathrm{P}<0.05$

$\mathrm{Pb}$ concentrations decreased compared to control group $(\mathrm{P}=0.030)$. Their habits of feeding on pavement and roadsides, and nesting in the smelter's courtyard alongside the lead in water, soil, sludge, ash $[1,14]$, and in petrol can justify the high levels of lead in the aforementioned tissues. As we described in Table 1, we found higher concentrations of $\mathrm{Pb}$ in the kidney, femur, and tibia. These results are in accordance with the results of many authors $[9,13]$ who found high levels of $\mathrm{Pb}$ in the femur and tibia in the natural population of feral pigeons and house sparrows living near Trepça smelter in Kosovo.

$\mathrm{Pb}$ accumulation in bones is less mobile, so it tends to be increased by time [20], and the high level of $\mathrm{Pb}$ in the solid tissue (femur and tibia) - higher than in the liver - can indicate for chronic toxicity [16]. In Kosovo even today, leaded petrol and fertilizers are used, which can explain the high level of $\mathrm{Pb}$ in the testes of feral pigeons from the control group. In the 20 samples of above-mentioned feral pigeon we found high levels of $\mathrm{Pb}$ in their blood [6].

The level of cadmium (Cd) concentrations in the liver and kidney increased $(\mathrm{P}=0.460 ; \mathrm{P} \leq 0.001)$, whereas in other tissues it is not found. These results are in accordance with the results of the other authors $[9,13]$, who reported the presence of cadmium in the liver and kidney of feral pigeon and house sparrows from areas near the smelters. The interaction between $\mathrm{Cd}$ and $\mathrm{Zn}$ in the natural population of feral pigeons has been reported previously $[13,16]$. Since the presence of $\mathrm{Cd}$ in the surface and ground waters of the Drenica was reported [14] and the zinc concentration in these tissues (liver and kidney), then the presence of $\mathrm{Cd}$ in the liver and kidney may be explained by the high level of $\mathrm{Zn}$ [16], knowing that $\mathrm{Pb}$ and $\mathrm{Cd}$ are competitive with $\mathrm{Zn}$ for the same bind-sites in many enzymes [16, 19-21].

Zinc $(\mathrm{Zn})$ concentrations in the liver, kidney, and tibia tissues increased $(\mathrm{P}=0.050, \mathrm{P}=0.094, \mathrm{P}=0.258)$, whereas in the testes and femur it decreased $(\mathrm{P} \leq 0.001$, $\mathrm{P}=0.556$ ). These results are in accordance with many authors [15] who treated Wistar rats with lead acetate and albino male rats with $\mathrm{Pb}$ and $\mathrm{Zn}$ [22]. In accordance with this are the results of other authors $[9,13]$, who have reported the high concentrations of $\mathrm{Zn}$ in feral pigeon 
tissues from the area of the Trepça smelter, where the $\mathrm{Cd}$ concentration also induced the concentration of $\mathrm{Zn}$. In the Drenas group, as a result of high concentrations of $\mathrm{Pb}$ and $\mathrm{Cd}$, it has brought to the increased concentration of $\mathrm{Zn}$ as a protective effect against intoxication and pollution with $\mathrm{Pb}$ and $\mathrm{Cd}[8]$. Due to increasing metallothionein - where $\mathrm{Pb}, \mathrm{Cd}$, and $\mathrm{Zn}$ compete for the same metal-binding sites in the target organs, such as liver, kidney, gonads, etc. then increasing $\mathrm{Pb}$ and $\mathrm{Cd}$ concentrations may lead to $\mathrm{Zn}$ concentrations [15]. Referring to this, in the testes, where the $\mathrm{Pb}$ concentration was higher in the control group, the $\mathrm{Zn}$ concentration was higher, too.

Copper $(\mathrm{Cu})$ concentration increased in the liver, kidney, testes, and tibia tissues $(\mathrm{P} \leq 0.001, \mathrm{P} \leq 0.001$, $\mathrm{P} \leq 0.001, \mathrm{P}=0.007)$, but it decreased in the femur tissue $(\mathrm{P}=0.456)$ compared to the control group. The presence of $\mathrm{Cu}$ in the soil, slag, and ash [1] in the area of the Drenas smelter may be brought to $\mathrm{Cu}$ accumulation in these tissues. Our results are in accordance with the results of the other authors, who have reported light increases of $\mathrm{Cu}$ in the liver and kidney of natural population of house sparrows living near the ferronickel smelter. It is known that the presence of $\mathrm{Pb}$ and $\mathrm{Zn}$ decreases the level of $\mathrm{Cu}$ [23]. Since the control area is the area that has highly developed agriculture, where pesticides containing copper are used, and on the other hand, copper can be decreased in the femur tissue due to the presence of the high level of $\mathrm{Pb}$ and $\mathrm{Zn}$ at the same time.

The level of nickel (Ni) concentration increased in the liver, kidney, testes, femur, and tibia $(\mathrm{P} \leq 0.001, \mathrm{P}=0.010$, $\mathrm{P}=0.292, \mathrm{P}=0.312, \mathrm{P}=0.102$ ) from the smelter courtyard compared to control. Regarding the accumulation of nickel, the pigeons in Drenas experienced an increase of $\mathrm{Ni}$, which was found in all tissues with emphasis on liver tissue (139.97 $\mu \mathrm{g} / \mathrm{mg}$ d.w.), when the increase was significantly higher $(\mathrm{P} \leq 0.001)$. This is in accordance with the results of other authors, who have found high levels of $\mathrm{Ni}$ in the tissues of bird populations [9, 13]. Knowing that the final products of the ferronickel smelter are Ni and $\mathrm{Fe}$, and the fact that the smelter has been operating since 1982, the high amounts of $\mathrm{Ni}$ and its compounds released into the air, water, and soil [1] may have brought about the nickel accumulation in all tissues. For the reason that $\mathrm{Ni}$ is an essential element, it may found in the tissue as a natural part of it. So, at the uncontaminated area it may range from $0.1-5 \mu \mathrm{g} / \mathrm{g}$ d.w. [13], but at high concentrations it cause disorders and diseases, including cancer [11]. Other authors have found nickel accumulation in the liver, kidney, testes, femur, and tibia of wild birds living near the smelters $[9,13]$, which is in accordance with our results.

\section{Conclusion}

This study has shown that feral pigeon can accumulate high levels of heavy metals $(\mathrm{Pb}, \mathrm{Cd}, \mathrm{Zn}, \mathrm{Cu}$, and $\mathrm{Ni}$ ) in soft (liver, kidney, testes) and solid (femur and tibia) tissues.
Due to their small weight and high metabolism, and their standing in the middle position of the food pyramid, feral pigeons can accumulate heavy metals in their tissues and provide us with important data about the effects of heavy metals in avian tissues. For this reason, feral pigeons can serve as important and suitable organisms for monitoring heavy metal pollution.

\section{Acknowledgements}

This research was partially supported by the Institute of Veterinary and Agriculture in Prishtina and the University of Prishtina (Faculty of Mathematical and Natural Sciences; Department of Biology; Republic of Kosovo). We are thankful to our colleague, Prof. Dr. Isa Elezaj, for his assistance with a critical review of the manuscript before submission.

\section{References}

1. DEMAKU S., DOBRA B., SHEHU I., KORCA B., SHALA F., KASTRATI G. Heavy Metals in the River Drenica (Kosova) From the Deposited Ash of the Complex "New Ferronickel". J. Int. Environmental Application \& Science. 7 (1), 178, 2012.

2. LETAJ K., ELEZAJ I., SELIMI Q., KURTESHI K. The Effects of Environmental Pollution with Heavy Metals in Frequency of Micronuclei in Epithelial Buccal Cells of Human Population in Mitrovica. Journal of Chemical Health Risks. 2 (3), 1, 2012.

3. BAOS R., JOVANI R., PASTOR N., TELLA J. L., JIMÉNEZ B., GÓMEZ G., GONZÁLEZ M.J., HIRALDO F. Evaluation of genotoxic effects of heavy metals and arsenic in wild nestling white storks (Ciconia ciconia) and black kites (Milvus migrans) from southwestern Spain after a mining accident. Environ Toxicol Chem. 25 (10), 2794, 2006.

4. IVANOVA E., STAYKOVA T., VELCHEVA I. Cytotoxicity and genotoxicity of heavy metal and cyanide-contaminated waters in some regions for production and processing of ore in bulgaria. Bulgarian journal of agricultural science. 14 (14), 262, 2008.

5. BOUNAGUA M., BELLAOUCHOU A., BENABBOU A., EL ABIDI A., BEN-AAKAM R., FEKHAOUI M. Using blood's Passer domesticus as a possible bio-indicator of urban heavy metals pollution in Rabat-Salé (Morocco). J. Mater. Environ. Sci. 5 (3), 937, 2014.

6. PLAKIQI M.A., SELIMI Q., LETAJ K., TREBICKA A. Lead Effect on Aminolevulinic Acid Dehydratase Activity of Feral Pigeon (Columba livia) in Drenas. Journal of Chemical Health Risks. 5,(4), 245, 2015.

7. GOVIND P., MADHURI S. Heavy Metals Causing Toxicity in Animals and Fishes. Research Journal of Animal, Veterinary and Fishery Sciences. 2 (2), 17, 2014.

8. GOERING P.L., WAALKES M.P., KLAASSEN C.D. Toxicology of cadmium. Toxicology of Metals. 204, 189, 1995.

9. ELEZAJ I., SELIMI Q., LETAJ K., PLAKIQI A., MEHMETI S.I., MILAIMI A. Metal Bioaccumulation, Enzymatic Activity, Total Protein and Hematology of Feral Pigeon (Columba Livia), Living in the Courtyard of Ferronickel Smelter in Drenas. Journal of Chemical Health Risks. 1 (1), 1, 2011. 
10. Agency for Toxic Substances and Disease Registry. TOXICOLOGICAL PROFILE FOR COOPER. http://www. atsdr.cdc.gov/toxprofiles/tp132.pdf. September 2004.

11. EISLER R. Nickel Hazards to fish, wildlife, and vertebrates: A synoptic review. Biological Science Report. No. USGS/ BRD/BSR--1998-0001. Geological survey Washington dc, 1998.

12. SÁNCHEZ-CHARDI A., OLIVEIRA R.C.A., NADAL $\mathrm{J}$. Metals in liver and kidneys and the effects of chronic exposure to pyrite mine pollution in the shrew Crocidura russula inhabiting the protected wetland of Doñana. Chemosphere. 76, 387, 2009.

13. OUTRIDGE P.M., SCHEUHAMMER A.M. Bioaccumulation and toxicology of nickel: implications for wild mammals and birds. Environmental Reviews. 1, 172, 1993.

14. DEMAKU S.I., SHEHU A., GJOKAJ K., KASTRATI A., BEHRAMI M., DEMAKU A., MALSIU A. Pollution of Lands, Surface and Groundwater with Heavy Metals around the Industrial Complex in Ferronickel. J. Int. Environmental Application \& Science. 9 (3), 440, 2014.

15. JELEA S.J., JELEA M. Effects of subacute treatment with lead acetate on the mineral constituents from femur and tibia. Carpathian Journal of Earth and Environmental Sciences. 4 (1), 61, 2009.

16. HUTTON M., GOODMAN G.T. Metal contamination of feral pigeons (Columba livia) from the London area:
Part 1-Tissue accumulation of Lead, Cadmium and Zinc. Environmental Pollution (Series A). 22 (3), 207, 1980.

17. MILLAKU L., IMERI R., TREBICKA A. House sparrow (Passer domesticus) as bioindicator of heavy metals pollution. European Journal of Experimental Biology. 4 (6), 77, 2014.

18. PAIN D.J., FISHER I.J., THOMAS V.G. A global update of lead poisoning in terrestrial birds from ammunition sources. Environmental pollution, 87, 173, 2009.

19. POUNDS J.G., LONG G.J., ROSEN J.F. Cellular and molecular toxicity of lead in bone. Environmental Helath Perspectives. 91, 17, 1991.

20. HASAN M.Z., SETH T.D. Effect of lead and zinc administration on liver, kidney and brain levels of copper, lead, manganese and zinc and on erythrocytes ALA-D in rats. Toxicology letters, 7 (4-5), 353, 1981.

21. Agency for Toxic Substances and Disease Registry. TOXICOLOGICAL PROFILE FOR ZINC. http://www. atsdr.cdc.gov/toxprofiles/tp60.pdf. August 2005.

22. VELIU A., GASHI S., RIZAJ M. Air Monitoring at Ferronikeli Smelter and Influence in the Environment. J. Int. Environmental Application \& Science, 4 (4), 428, 2009.

23. BLANUSA M., BRESKI D. Comparison of dry and wet ashing procedures for cadmium and iron determination in biological material by atomic-absorption spectrophotometry. Talanta, 28, 681, 1981. 